\title{
Pliocene Model Intercomparison Project Experiment 1: implementation strategy and mid-Pliocene global climatology using GENESIS v3.0 GCM
}

\author{
S. J. Koenig ${ }^{1}$, R. M. DeConto ${ }^{1}$, and D. Pollard ${ }^{2}$ \\ ${ }^{1}$ Department of Geosciences, University of Massachusetts Amherst, 611 N. Pleasant Street, Amherst, MA 01003, USA \\ ${ }^{2}$ Earth and Environmental Systems Institute, College of Earth and Mineral Sciences, Pennsylvania State University, \\ 2217 Earth-Engineering Sciences Bldg., University Park, PA 16802, USA
}

Correspondence to: S. J. Koenig (koenig@geo.umass.edu)

Received: 1 September 2011 - Published in Geosci. Model Dev. Discuss.: 4 October 2011

Revised: 30 November 2011 - Accepted: 19 December 2011 - Published: 18 January 2012

\begin{abstract}
The mid-Pliocene Warm Period (3.29 to 2.97 Ma BP) has been identified as an analogue for the future, with the potential to help understand climate processes in a warmer than modern world. Sets of climate proxies, combined to provide boundary conditions for Global Climate Model (GCM) simulations of the mid-Pliocene, form the basis for the international, data-driven Pliocene Model Intercomparison Project (PlioMIP). Here, we outline the strategy for implementing pre-industrial (modern) and mid-Pliocene forcings and boundary conditions into the GENESIS version 3 GCM, as part of PlioMIP. We describe the prescription of greenhouse gas concentrations and orbital parameters and the implementation of geographic boundary conditions such as land-ice-sea distribution, topography, sea surface temperatures, sea ice extent, vegetation, soils, and ice sheets. We further describe model-specific details including spin-up and integration times. In addition, the global climatology of the mid-Pliocene as simulated by the GENESIS v3 GCM is analyzed and compared to the pre-industrial control simulation. The simulated climate of the mid-Pliocene warm interval is found to differ considerably from pre-industrial. We identify model sensitivity to imposed forcings, and internal feedbacks that collectively affect both local and far-field responses. Our analysis points out the need to assess both the direct impacts of external forcings and the combined effects of indirect, internal feedbacks. This paper provides the basis for assessing model biases within the PlioMIP framework, and will be useful for comparisons with other studies of mid-Pliocene climates.
\end{abstract}

\section{Introduction}

The mid-Piacenzian or mid-Pliocene Warm Period (3.29 to 2.97 Ma BP, hereafter Pliocene), had global mean surface temperatures in the range of those projected for the end of the 21 st century. Boundary conditions and forcings, including atmospheric $p \mathrm{CO}_{2}$ mixing ratios $(\sim 400 \mathrm{ppmv})$, were similar to today (e.g., Pagani et al., 2009). The Pliocene therefore serves as a useful analogue for future climate and provides a framework for testing the longer-term response of the global system to higher-than modern temperatures on $\sim 10^{5}$ yr timescales. The international Paleoclimate Modeling Intercomparison Project (PMIP) was recently extended to include the mid-Pliocene warm period, combining available and accessible data reconstructions and numerical modeling initiatives. The Pliocene Model Intercomparison Project, PlioMIP (Haywood et al., 2010, 2011) aims at reconstructing the climate of the Pliocene and comparing a set of Global Climate Models (GCMs) utilizing the same boundary conditions and forcings. Planned analyses focus on the intercomparison of two experiments using atmosphereonly (Experiment 1) and coupled Ocean-Atmosphere Circulation Models (Experiment 2). Both mid-Pliocene experiments are compared to a pre-industrial control run to quantify climate change and to identify biases. Over the past few decades, the US Geological Survey PRISM project (Pliocene Research, Interpretation and Synoptic Mapping, Dowsett et al., 1994) has generated data sets for the midPiacenzian warm period, with more than a million individual measurements providing well-constrained boundary conditions for modeling experiments. The latest iteration of 
the PRISM palaeoenvironmental reconstruction PRISM3D (Dowsett et al., 2010) is implemented in the PlioMIP specifications for the mid-Pliocene experiments.

Here, we present the implementation of boundary conditions and experimental design of Experiment 1 of PlioMIP, using the atmospheric and land components of the GENESIS v3 GCM following the strategy presented in Haywood et al. (2010). This detailed documentation will prove valuable for further PlioMIP planned intercomparisons, and will help to better assess model-specific biases. In addition to the implementation of boundary conditions, basic results of surface air temperatures, precipitation rates and energy balance are analyzed, along with differences between simulations of pre-industrial climate and the mid-Pliocene warm period.

\section{Experimental design}

\subsection{GENESIS general circulation model version 3}

We use the current version 3 of the Global ENvironmental and Ecological Simulation of Interactive Systems (GENESIS) GCM, originally developed by the Interdisciplinary Climate Systems Section of the Climate and Global Dynamics Division at NCAR (Thompson and Pollard, 1997). The model consists of coupled global models of the atmosphere, ocean, vegetation, soil, snow, ice sheets, and sea ice. The 3-D atmospheric general circulation model (AGCM) uses an adapted version of the NCAR CCM3 solar and thermal infrared radiation code (Kiehl et al., 1998) and is coupled to the surface components by a land-surface-transfer scheme (LSX). Vegetation distributions and their physical attributes can be provided in multiple ways, either using prescribed data sets (Dorman and Sellers, 1989, see below), or from interactively coupled, predictive vegetation models (e.g., EVE Bergengren et al., 2001 and BIOME4 Kaplan et al., 2003; Koenig et al., 2011). The ocean can be represented either by prescribed climatological sea-surface-temperatures and sea ice, by a predictive 50-m slab diffusive mixed-layer and dynamical sea-ice model, or by a 3-D ocean GCM (Pacanowski, 1996; Zhou et al., 2008; Alder et al., 2011). The GENESIS GCM has been validated against modern climate and used extensively for paleoclimatic simulations (e.g., Thompson and Pollard, 1997; Mathieu et al., 2002; Pollard and PMIP Groups, 2000; DeConto et al., 2007 and references therein). In the configuration used here, the model atmosphere has a spectral resolution of $\mathrm{T} 31\left(\sim 3.75^{\circ}\right)$ with 18 vertical layers. Surface components and LSX are on a regular $2^{\circ} \times 2^{\circ}$ grid.

\subsection{Implementation strategy}

\subsubsection{General set-up}

The general model set-up described in this section serves as the basis for both pre-industrial and Pliocene experiments. Experiment-specific definitions and modifications are then documented in separate sections below (see Sects. 2.2.2, and 2.2.3).

The GENESIS AGCM and surface models use input files that specify global maps of topography, surface type (landice-ocean), vegetation distribution, soil texture and other quantities. We use the preferred set of PMIP3 input files (Haywood et al., 2010) for pre-industrial and Pliocene experiments, and adapt them to match the GENESIS GCM specific-input formats and spatial resolutions $\left(2^{\circ} \times 2^{\circ}\right.$ and spectral T31 $\left(3.75^{\circ} \times 3.75^{\circ}\right)$ grids for surface and AGCM models, respectively). For Experiment 1, we run both the pre-industrial control and the Pliocene atmosphere-only experiments for $50 \mathrm{yr}$ (the preferred PlioMIP mode). Spin-up is taken into account, and equilibrium is effectively reached after a few years of integration (Fig. 1). The results presented here (see Sect. 3) are averages over the last 30 years of each 50 -yr simulation.

Greenhouse gas volume mixing ratios are set to the preferred PMIP3 values and are identical in both pre-industrial control and the Pliocene, except for atmospheric $p \mathrm{CO}_{2}$ (see below). The GENESIS $\vee 3$ GCM sensitivity to a doubling of $\mathrm{CO}_{2}$ is $2.9^{\circ} \mathrm{C}$, which is close to the average among IPCCclass GCMs. We specify $270 \mathrm{ppb}$ for $\mathrm{N}_{2} \mathrm{O}$ and $760 \mathrm{ppb}$ for $\mathrm{CH}_{4}$. $\mathrm{CFCl}_{3}$ defaults to $0.238 \mathrm{ppm}$, and $\mathrm{CF}_{2} \mathrm{Cl}_{2}$ to $0.408 \mathrm{ppm}$. Aerosols are prescribed using default preindustrial levels. Prescribed atmospheric ozone amounts are set to zero for solar and infrared radiative calculations. The solar constant is set to the preferred PMIP3 value of $1365 \mathrm{~W} \mathrm{~m}^{-2}$. Orbital eccentricity, obliquity and precession are set to $0.016724,23.446^{\circ}$ and $102.04^{\circ}$ (perihelion minus $180^{\circ}$ ), respectively. As described in Pollard and Thompson (1997), the GENESIS GCM precessional input $(\Omega)$ is defined as the prograde angle from perihelion to the northern hemispheric vernal equinox. The PlioMIP precessional specification is converted to the GENESIS value accordingly.

Both the pre-industrial control and Pliocene experiment (1) are initialized as "cold starts", with zonally symmetric and vertically uniform temperatures, varying smoothly from $285^{\circ} \mathrm{K}$ at the equator to $275^{\circ} \mathrm{K}$ at the poles (Thompson and Pollard, 1995).

Sea surface temperatures and sea-ice extents are prescribed, which is PlioMIP's preferred ocean mode. This prescribed ocean climatology is based on PRISM3 and uses 12 monthly input data files, defining monthly mean sea surface temperatures and sea ice extents. The single annual cycle of prescribed Pliocene ocean conditions is repeated each year of the model run.

\subsubsection{Pre-industrial atmosphere-only PlioMIP experiment}

The pre-industrial control experiment uses GENESIS modern input files in combination with the general PlioMIP setup described above. 


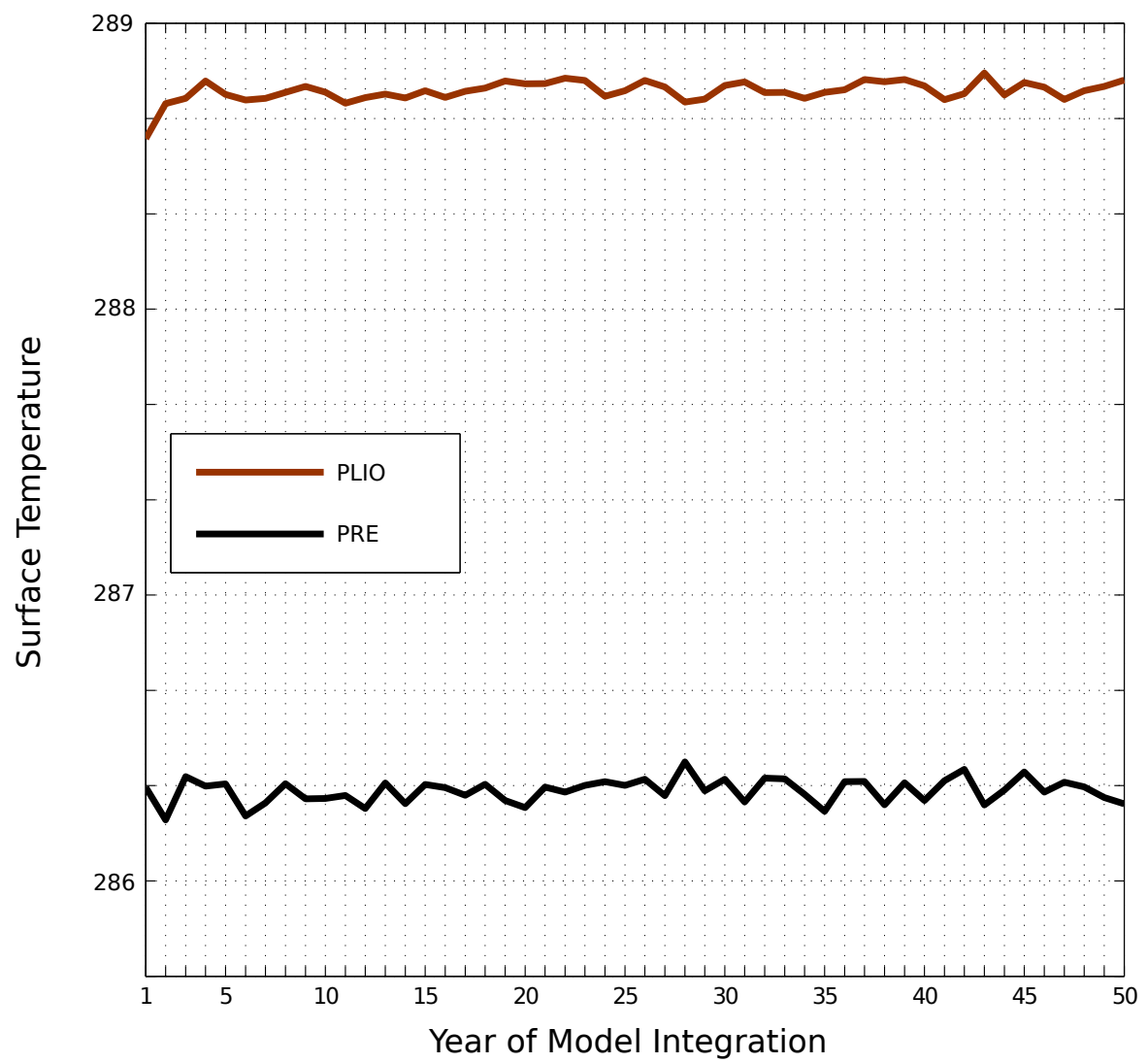

Fig. 1. Equilibration time for scenarios using the atmospheric component of the coupled GENESIS v3. GCM. Surface temperature (2-m) $\left({ }^{\circ} \mathrm{K}\right)$ for pre-industrial (black) and Pliocene scenario (dark red) for Experiment 1 for year 1 to 50 of the integration. Results presented herein are averaged over the last 30 years of each integration.

PlioMIP guidelines direct modeling groups to use their own land-sea mask and topography for the pre-industrial experiment. We use the topography field from the US Navy FNOC global elevation set of $10 \mathrm{~min}$ resolution (Kineman, $1985)$ and areally average it to the model's $2^{\circ} \times 2^{\circ}$ grid for the AGCM topography field (Fig. 2). The land-ice sheet-ocean mask for the surface models is based on the same data, except ice sheet areas are superimposed using the $1^{\circ} \times 1^{\circ}$ Global Hydrographic Dataset of Cogley (1991). The resulting mask differentiates between land, ice sheets and ocean. In both pre-industrial and Pliocene experiments the Central American Seaway is prescribed to be closed, while the Bering Strait, Drake Passage, Tasman Gateway, Gibraltar Strait and Indonesian Gateway are open (Fig. 3), although the ocean gateways have little impact on simulations using prescribed SSTs. A comparison of GENESIS and PlioMIP pre-industrial topographies shows generally small differences. Larger deviations exist in high mountain ranges due to single-grid-cell discrepancies between the datasets (Fig. 2).

Vegetation distributions are prescribed based on Dorman and Sellers (1989), with physical attributes and seasonal cycles of leaf area index (phenology) for each biome updated daily (see also Lapola et al., 2008). Following Haywood et al. (2010), we compare vegetation of the preindustrial scenario to observations in order to ensure that the re-classification leads to meaningful biome patterns before applying the transfer scheme to the Pliocene. We find that pre-industrial patterns compare favorably to independent pollen-based patterns (Prentice and Jolly, 2000; Harrison et al., 2001; Bigelow et al., 2003), reconstructions of potential natural vegetation (Ramankutty and Foley, 1999) and modeling studies, e.g., Wohlfahrt et al. (2004) for modern day (not shown). We re-classify the mega-biomes of BAS BIOME4 modern and PRISM3D vegetation (Harrison and Prentice, 2003) into the 12 biome types of Dorman and Sellers (1989) following the key presented in Table 1, and transfer them to the GCM surface grid. Tundra and dry tundra in Harrison and Prentice (2003) are not distinguished in the final classification. Figure 4 presents the global, reclassified vegetation distribution that serves as the basis for the pre-industrial experiment. The re-classified global vegetation distribution adequately reproduces the original modern vegetation map of Dorman and Sellers (1989). 

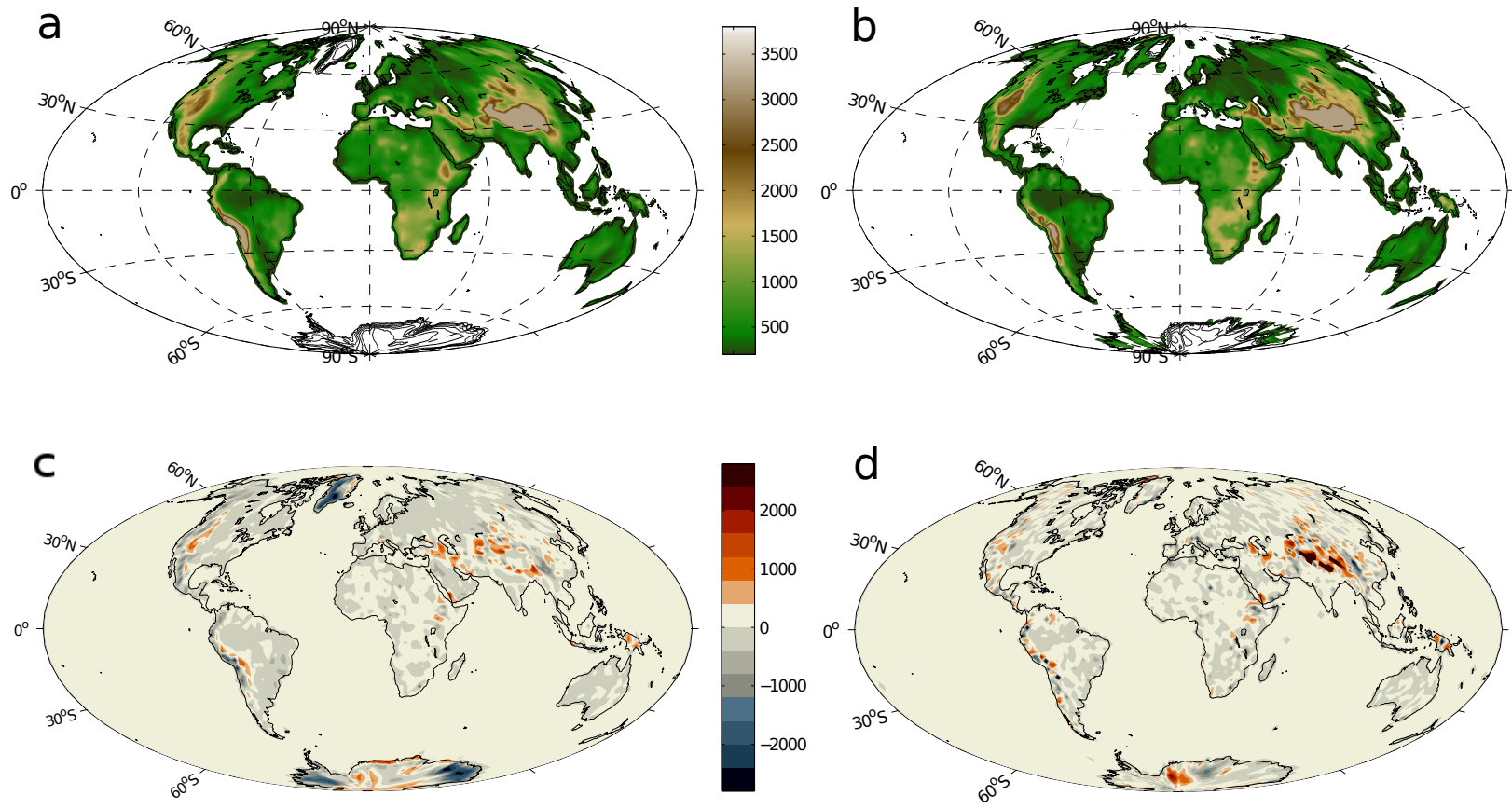

Fig. 2. Boundary conditions. Absolute global topography $(\mathrm{m})$ for (a) pre-industrial (Topo pre.genesis), and (b) mid-Pliocene (Topo ${ }_{\text {plio.genesis }}$ ) experiments. Mid-Pliocene final topography is calculated using an anomaly approach (see text). Elevation differences (m) (c) between (b-a),

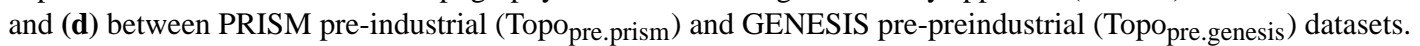

For the pre-industrial experiment, monthly sea-surface temperatures (SST) and sea-ice extents are prescribed using the Shea et al. (1991) global dataset. This monthly climatology is linearly interpolated in time between the dataset's mid-month values. Figure 5d shows the difference between modern GENESIS SSTs and PRISM data sets. Deviations are generally less than $\pm 0.5^{\circ} \mathrm{C}$ and are not statistically different, as inferred from a Student t-test.

Global maps of soil texture for the 6 GENESIS soil layers are derived from the dataset of Webb et al. (1993), which combines a $1^{\circ} \times 1^{\circ}$ global map of soil types with UNESCO texture information versus depth. Soil textures are left unchanged in modern experiments.

As mentioned above, atmospheric greenhouse gas levels are set to preferred PlioMIP values, with carbon dioxide volumetric mixing ratio at the pre-industrial level of $280 \mathrm{ppm}$.

\subsubsection{Pliocene atmosphere-only PlioMIP experiment}

For the mid-Pliocene experiment we use preferred PRISM3D data files for the land-ice-sea mask, topography, ice sheet configuration, vegetation distribution, sea surface temperatures, and sea ice distribution, and convert them to the GENESIS input format.

The preferred PlioMIP land fraction mask is first used to generate a modified GENESIS GCM surface mask input file, which then serves to distinguish land, ocean and ice-sheet points for all other adapted input files for the Pliocene experiment (see below).

In order to compare differences due to the physics of the GCMs themselves, rather than differences in their modern boundary conditions, we use the anomaly approach as described in Haywood et al. (2010) to create the Pliocene topography map on a $2^{\circ} \times 2^{\circ}$ grid.

Topo $_{\text {plio.genesis }}=$
$\left(\right.$ Topo $_{\text {plio.prism }}-$ Topo $\left._{\text {pre.prism }}\right)+$ Topo $_{\text {pre.genesis }}$

For grid-cells where a potential mismatch between Pliocene and pre-industrial topography exists, the absolute

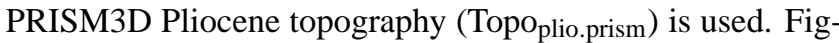
ure 2 shows pre-industrial and Pliocene topographies and differences between them. Significant elevation differences between reconstructed Pliocene and pre-industrial experiments exist in areas where ice-sheet reconstructions deviate from modern, namely South and West Greenland, West Antarctica, and the Aurora and Wilkes sector on East Antarctica. Note that ice shelves in Pliocene Antarctica are not modelled in ice sheet simulations providing the basis for the PRISM3D distribution of Pliocene ice (see Hill et al., 2007), so there is no extensive marine-based ice sheet on West Antarctica. The Pliocene Rocky Mountains/Colorado Plateau and Andes contain regions that are notably higher, with topographic anomalies of $+900-1200 \mathrm{~m}$ compared to the pre-industrial (Fig. 2). 

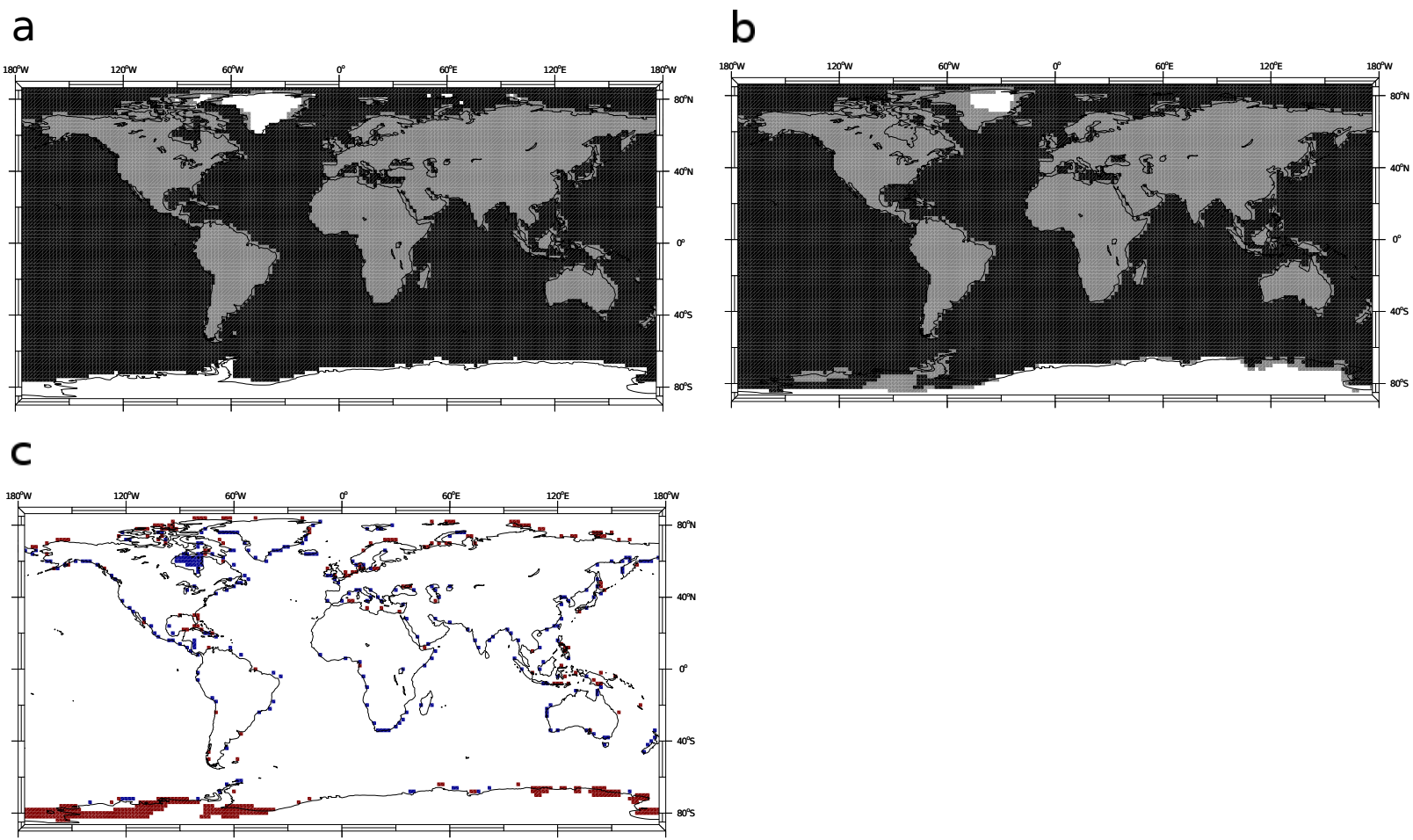

Fig. 3. Boundary conditions. Land-ice-ocean mask for (a) pre-industrial, and (b) Pliocene scenarios. (c) Grid-cell specific deviations of land and ocean between Pliocene and pre-industrial masks, with land (blue) and ocean (red) cells present in Pliocene scenario and absent in pre-industrial. Note that pre-industrial mask is adapated to Pliocene mask for anomaly calculation (see text).

Table 1. Vegetation megabiomes of Harrison and Prentice (2003) (HP2003) reclassified into Dorman and Sellers (1989) biomes (DS89).

\begin{tabular}{rlll}
\hline HP2003 & Classification & DS89 & Classification \\
\hline 0 & sea & 1 & Broadleaf-evergreen trees \\
1 & tropical forest & 12 & Broeadleaf-deciduous trees with winter wheat \\
2 & warm-temperate forest & 6 & Broeadleaf trees with groundcover \\
3 & savanna and dry woodland & 8 & Broeadleaf shrubs with groundcover \\
4 & grassland and dry shrubland & 11 & No vegetation; bare soil \\
5 & desert & 3 & Broadleaf and needleaf trees \\
6 & temperate forest & 4 & Needleleaf-evergreen trees \\
7 & boreal forest & 10 & Dwarf trees and shrubs with groundcover \\
8 & tundra & 10 & Dwarf trees and shrubs with groundcover \\
9 & dry tundra & 20 & Perennial ice \\
28 & land ice &
\end{tabular}

River routes follow modern topography except where inappropriate due to changes in the Pliocene land/sea mask where rivers are routed to the nearest ocean grid box.

Unlike PlioMIP's input data files (Haywood et al., 2010), ice-sheet and vegetation distributions are represented in separate input files within GENESIS. There is no a priori ice sheet input file for the GENESIS GCM, and PRISM3D ice locations are incorporated into the GENESIS surface mask input file. Additionally, ice sheets are assigned in the landsea mask where we translate PRISM3D ice sheet locations into the adapted surface mask input file (see Fig. 3).
The same anomaly method as above is used for Pliocene SSTs, using reconstructed PRISM3D and modern ocean temperature fields (Dowsett et al., 2010) and modern GENESIS SST fields (Shea et al., 1991, see above).

$$
\begin{aligned}
& \mathrm{SST}_{\text {plio.genesis }}= \\
& \left(\mathrm{SST}_{\text {plio.prism }}-\mathrm{SST}_{\text {pre.prism }}\right)+\mathrm{SST}_{\text {pre.genesis }}
\end{aligned}
$$

The modern SST map is projected directly onto the same Pliocene (land-sea) grid, making differences between simulations easy to determine. Reconstructed sea ice cover is then superposed onto the gridded SSTs. Figure 5 compares 


\section{a}
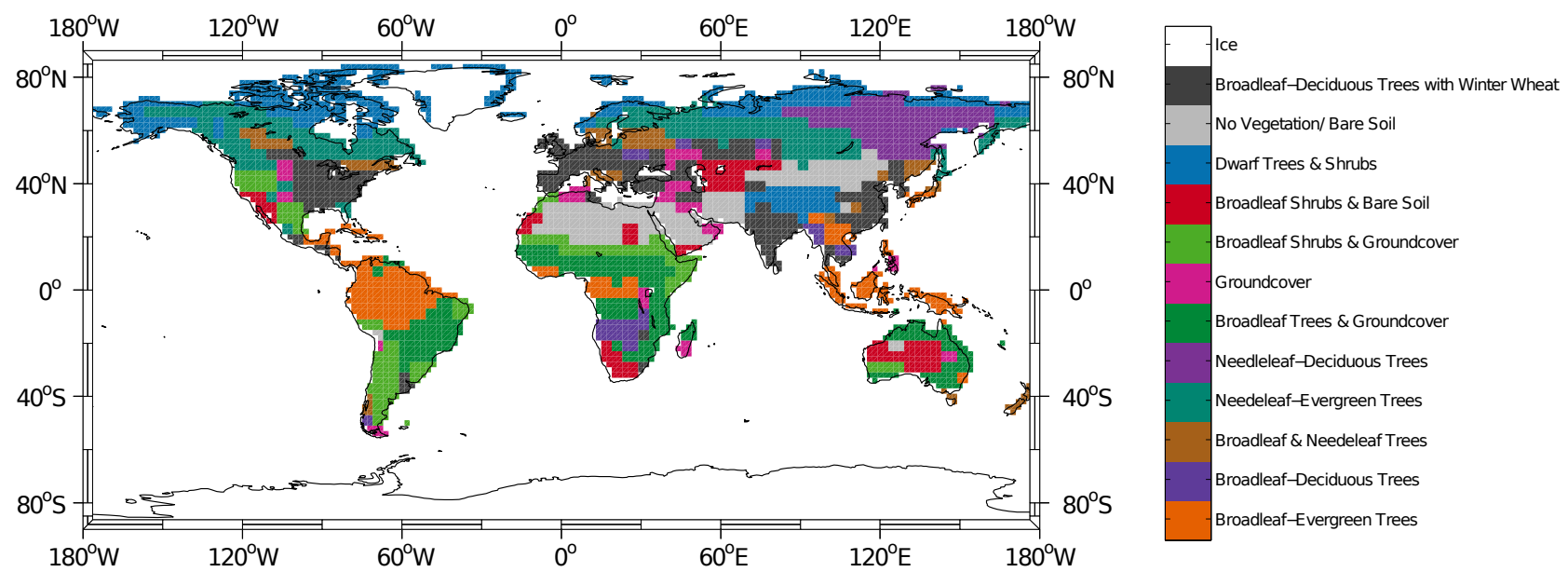

b

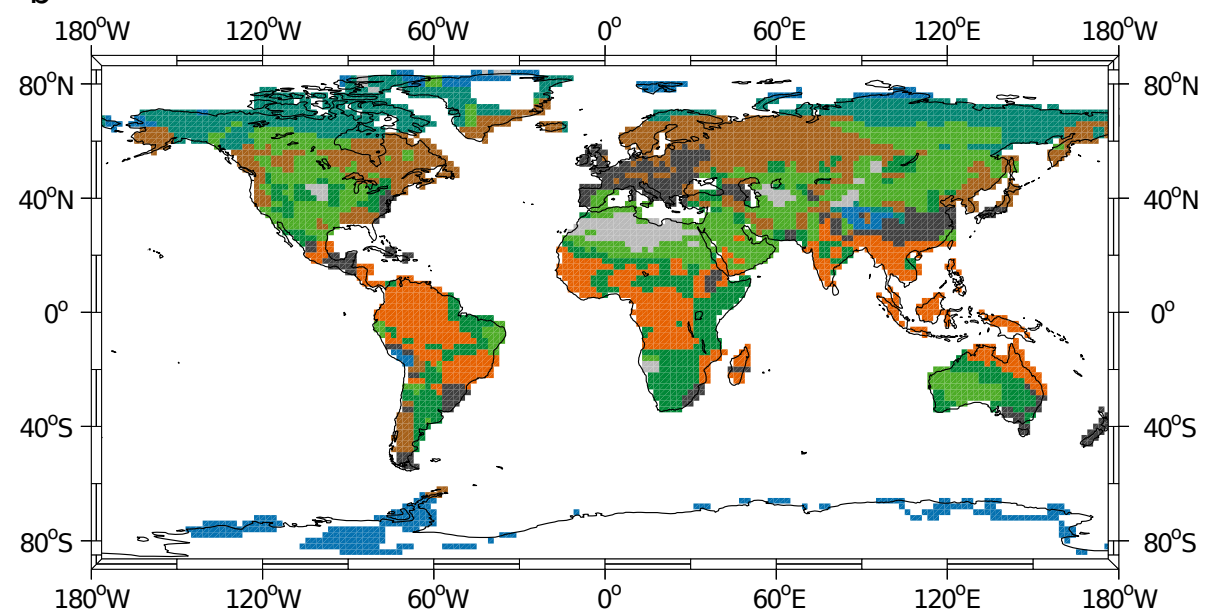

Fig. 4. Boundary conditions. Re-classified mega-biome distribution of Dorman and Sellers (1989) for (a) pre-industrial, and (b) mid-Pliocene vegetation input files.

absolute pre-industrial and Pliocene SSTs. In tropical and low latitudes, mid-Pliocene SSTs are generally within $\Delta<1^{\circ} \mathrm{C}$ of pre-industrial values (except for the Eastern Pacific). High-latitude anomalies range up to $12{ }^{\circ} \mathrm{C}$ with largest differences in the North Atlantic.

As mentioned above, BAS BIOME4 Pliocene vegetation types are re-classified to Dorman and Sellers (1989) biomes (Table 1). The resulting Pliocene biome distribution differs considerably from the pre-industrial pattern at all latitudes (Fig. 4). In the Pliocene, broadleaf-evergreen trees expand from equatorial regions into low latitudes of both hemispheres. In low to mid-latitudes, Pliocene deserts are reduced in area, replaced mainly by broadleaf shrubs. In mid latitudes, broadleaf and needleleaf trees increase in area at the expense of needleleaf-evergreen trees. High latitude northern hemispheric tundra is pushed northward by needleleafevergreen trees, significantly reducing the total areal extent of Pliocene tundra. In the Pliocene, ice-free areas of
Antarctica are covered by tundra, whereas coastal broadleaf trees (South) and needleleaf-evergreen trees (West) dominate Greenland.

Prescribed distributions of soil texture in both modern and Pliocene simulations use the preferred PlioMIP soil texture data set, based on modern soil types. Soil textures, defined by fractional percentages of sand, silt and clay, are defined for each of the 6-levels in the LSX soil model and adapted to the Pliocene land-surface grid. Potential mismatches are corrected for those grid cells where no information was given by creating values from the nearest available neighbors.

\section{Mid-Pliocene climatology from GENESIS GCM v3}

Basic climatological parameters are analyzed to describe the general mid-Pliocene climatology simulated by the GENESIS v3 GCM in response to forcings and boundary conditions described above. Results of surface air temperatures, 

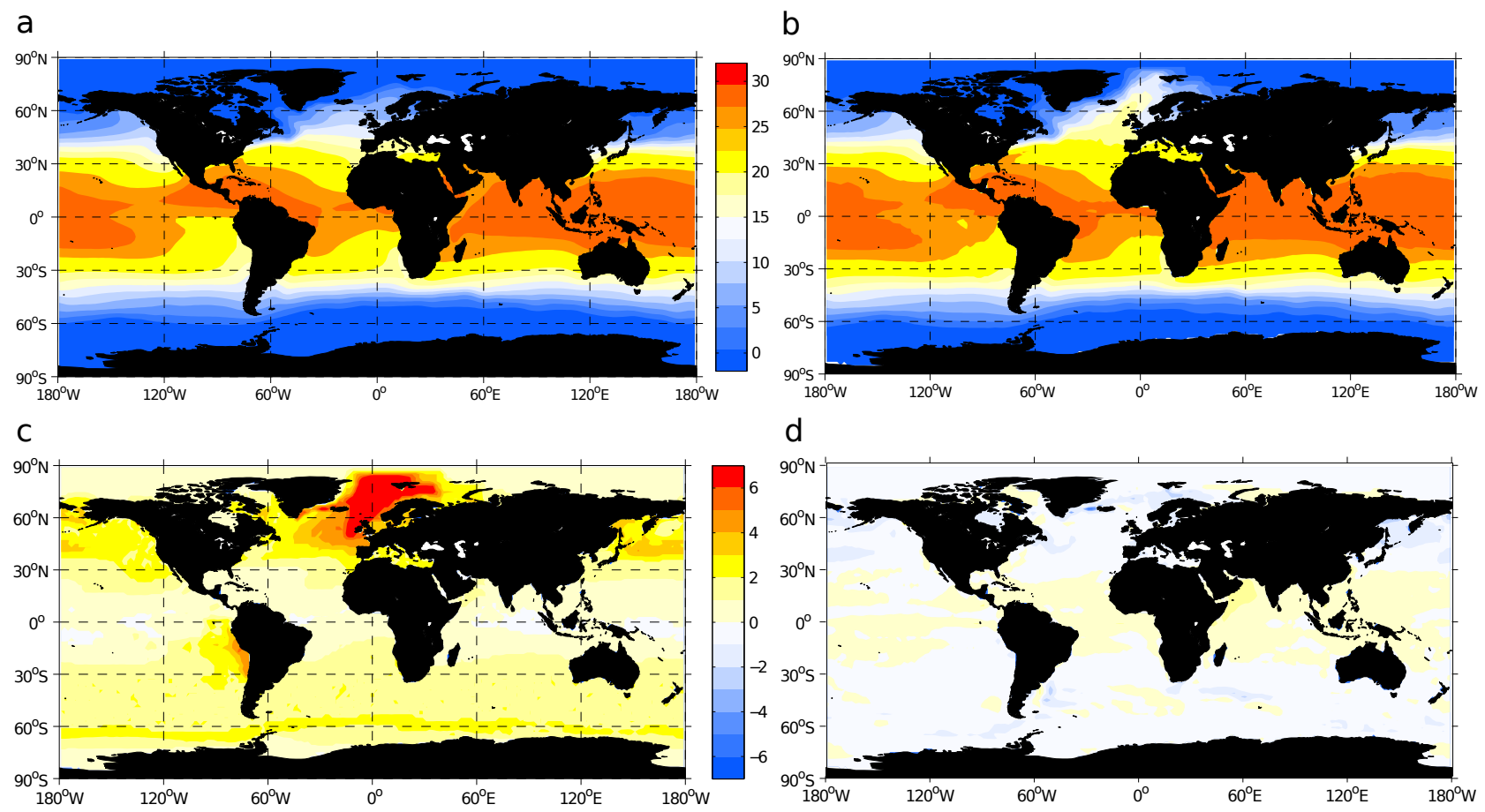

Fig. 5. Boundary conditions. Absolute annual global sea surface temperatures $\left({ }^{\circ} \mathrm{C}\right)$ for (a) pre-industrial (SST $\left.\mathrm{Sre}_{\text {genesis }}\right)$, and $(\mathbf{b})$ mid-

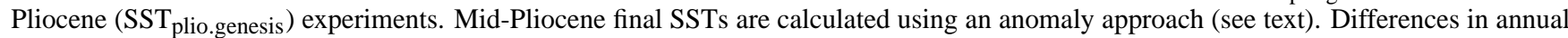

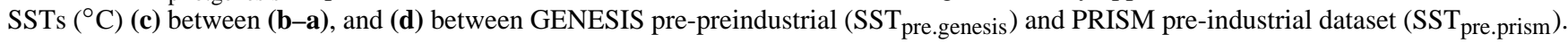

precipitation rates and surface energy balance, for land and ocean, annually and seasonally are discussed relative to the pre-industrial climate.

In most regions and seasons, modeled Pliocene surface air temperatures are warmer than modern (Figs. 6 and 8) in response to increased Pliocene sea surface temperatures, reduced ice sheets and altered vegetation distribution. Zonal mean positive anomalies increase from $2{ }^{\circ} \mathrm{C}$ in the tropics, to $13^{\circ} \mathrm{C}$ at around $70-80^{\circ} \mathrm{N}$, as a result of ice albedo and ice height feedbacks. Zonal mean warming at high latitudes is dominated by the effects of ice-sheet elevation changes on Greenland and Antarctica, and albedo feedbacks where reconstructions of grounded ice and sea ice deviate between Pliocene and pre-industrial scenarios (see Fig. 2). We calculate albedo from surface fluxes and find maximum differences $(>0.5)$ over southern Greenland, Arctic Ocean, West Antarctica, and the Southern Ocean (Fig. 7). Reductions in albedo significantly impact sensible and latent heat fluxes from land/ocean into the atmosphere (not shown). Albedo changes over the fixed East Antarctic Ice Sheet are not significant. In high northern latitudes, the largest warming occurs in the North Atlantic, and is seasonally greatest in winter when sea-ice reduction and contrasting air and ocean temperatures have their maximum effect. The mean annual global temperature for the Pliocene is $15.5^{\circ} \mathrm{C}$ compared to $13.3^{\circ} \mathrm{C}$ for pre-industrial, with greater warming in northern hemispheric winter $\left(2.3{ }^{\circ} \mathrm{C}\right)$ than summer $\left(1.9^{\circ} \mathrm{C}\right.$, Table 2). Prescribed elevation changes in the Pliocene Andes and Rocky Mountains/Colorado Plateau (see Fig. 2) cause expected (lapse-rate) temperature differences.

Table 2 summarizes winter, summer and annual global averages for net upward energy fluxes at the top of the atmosphere and surface. The net upward radiation (emitted infrared minus absorbed solar) at the top of the atmosphere is less in all seasons of the Pliocene scenario compared to preindustrial, with maximum difference of $-2 \mathrm{~W} \mathrm{~m}^{-2}$ in boreal summer. The total global net surface energy flux $F_{\text {snet }}$ $\left(\mathrm{W} \mathrm{m}^{2}\right)$ is calculated from all surfaces as follows.

$F_{\text {snet }}=-\mathrm{SW}+\mathrm{LW}+S_{\mathrm{h}}+L_{\mathrm{h}}$

where $L_{\mathrm{h}}$ and $S_{\mathrm{h}}$ are upward latent and sensible heat fluxes, and LW and SW are the net upward longwave and downward shortwave radiative fluxes at the surface. Global $F_{\text {snet }}$ differences between Pliocene and pre-industrial are $-1.3 \mathrm{~W} \mathrm{~m}^{-2}$ in winter and $-2.2 \mathrm{~W} \mathrm{~m}^{-2}$ in summer with an annual anomaly of $-1.3 \mathrm{~W} \mathrm{~m}^{-2}$ with respect to the control simulation.

Global and annual mean precipitation increases by $5-10 \%$ in the Pliocene compared to pre-industrial, with little difference between winter and summer (Table 2). Significant positive anomalies occur over some tropical land regions and also in higher latitudes, with maximum increases over the North 
a

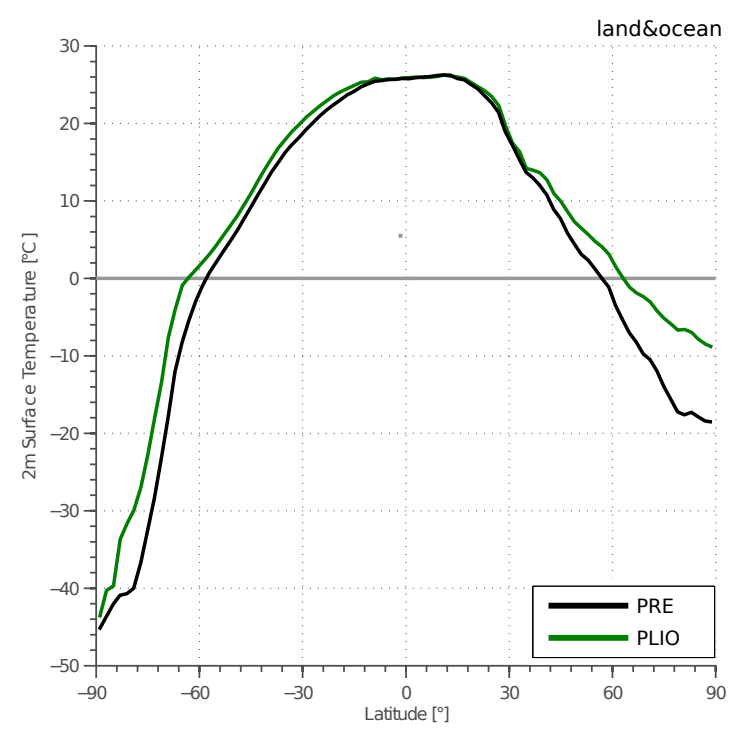

C

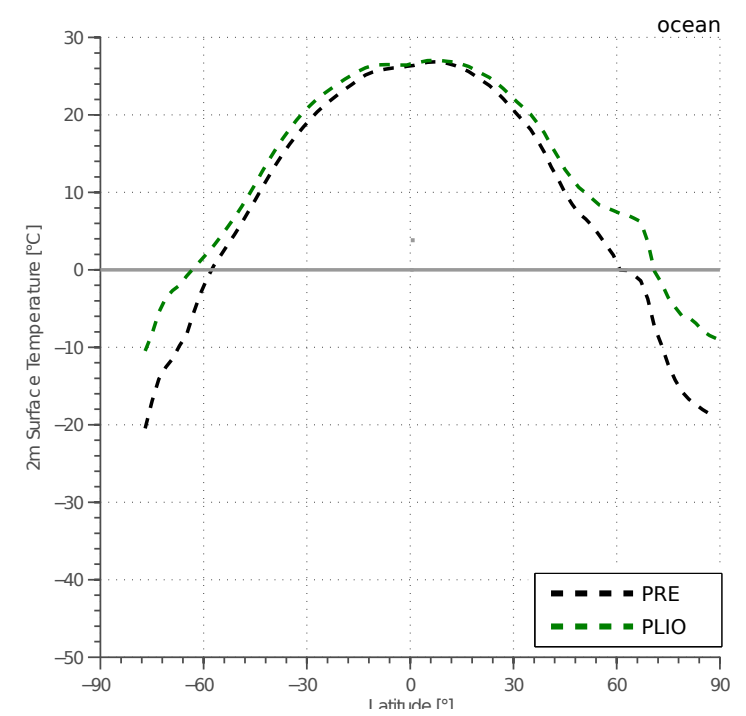

b

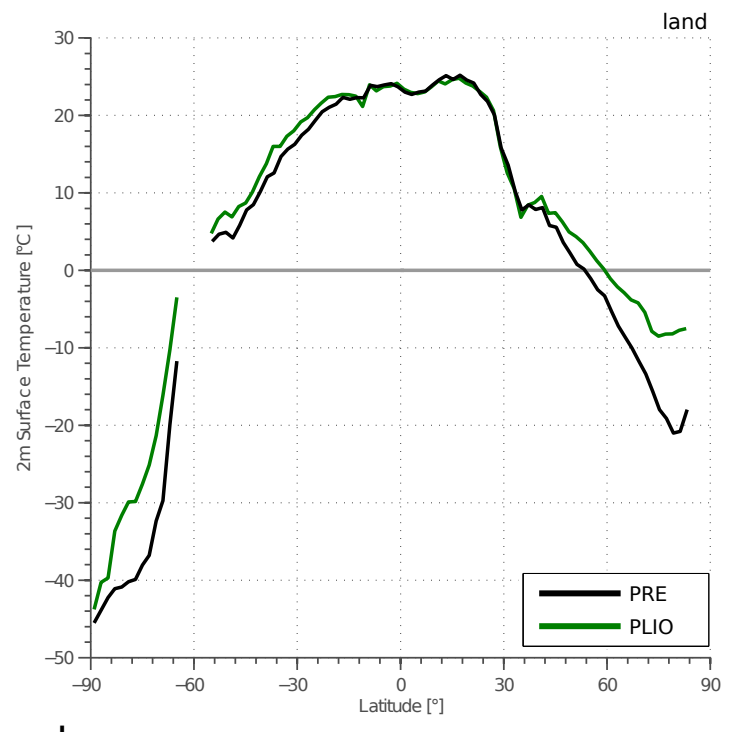

d

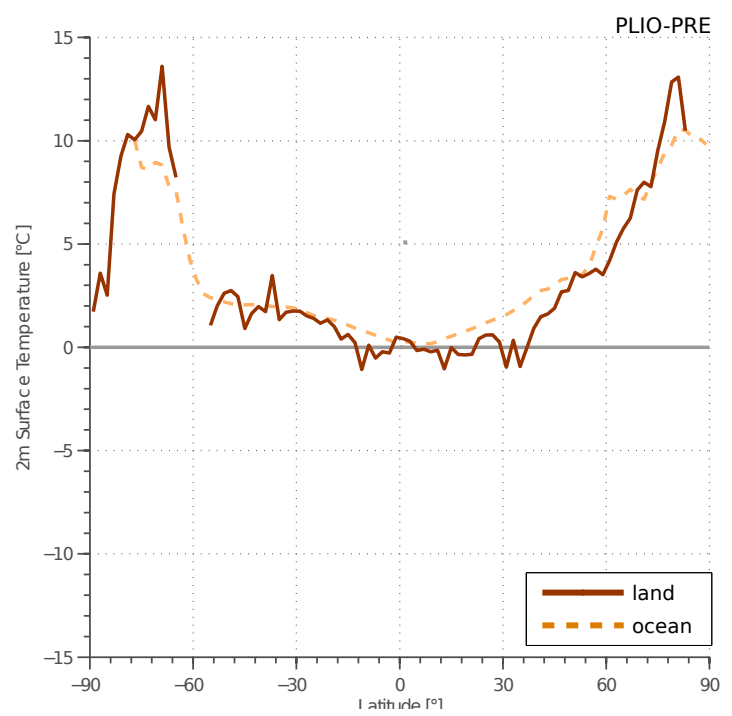

Fig. 6. Latitudinally averaged surface temperatures $\left({ }^{\circ} \mathrm{C}\right)$ for (a) land and ocean, (b) land only, and (c) ocean only grid cells for pre-industrial (black) and mid-Pliocene (green) experiments. (d) Differences in zonal mean surface temperatures $\left({ }^{\circ} \mathrm{C}\right.$ ) between mid-Pliocene and preindustrial scenarios for land (solid red) and ocean (dashed orange).

Table 2. Boreal summer (JJA), winter (DJF) and annual (ANN) global climatological means of net upward energy flux for top-of-atmosphere (TOA) and surface $\left(\mathrm{W} \mathrm{m}^{-2}\right)$, surface temperature $\left({ }^{\circ} \mathrm{C}\right)$ and precipitation rate $\left(\mathrm{mm} \mathrm{d}^{-1}\right)$ for pre-industrial (PRE), mid-Pliocene (PLIO), and differences between scenarios (PLIO-PRE). Note that a known long-standing spurious net energy sink of $\sim 2.0 \mathrm{~W} \mathrm{~m}^{-2}$ in the GENESIS atmospheric model (due to inexact treatment of water-vapor specific heat in the spectral dynamics) should be taken into consideration when comparing all top-of-atmosphere upward fluxes.

\begin{tabular}{|c|c|c|c|c|c|c|c|c|c|c|c|c|}
\hline & \multicolumn{3}{|c|}{ TOA Energy } & \multicolumn{3}{|c|}{ Surface Energy } & \multicolumn{3}{|c|}{ Temperature } & \multicolumn{3}{|c|}{ Precipitation } \\
\hline & JJA & DJF & ANN & JJA & DJF & ANN & JJA & DJF & ANN & JJA & DJF & ANN \\
\hline PRE & 11.3 & -6.1 & 2.2 & 16.1 & -2.8 & 5.4 & 15.1 & 11.5 & 13.3 & 3.3 & 3.0 & 3.2 \\
\hline PLIO & 9.3 & -7.9 & 0.5 & 13.9 & -4.1 & 4.1 & 17.0 & 13.8 & 15.5 & 3.4 & 3.2 & 3.3 \\
\hline$\triangle$ PLIO-PRE & -2 & -1.8 & -1.7 & -2.2 & -1.3 & -1.3 & 1.9 & 2.3 & 2.2 & 0.2 & 0.2 & 0.2 \\
\hline
\end{tabular}



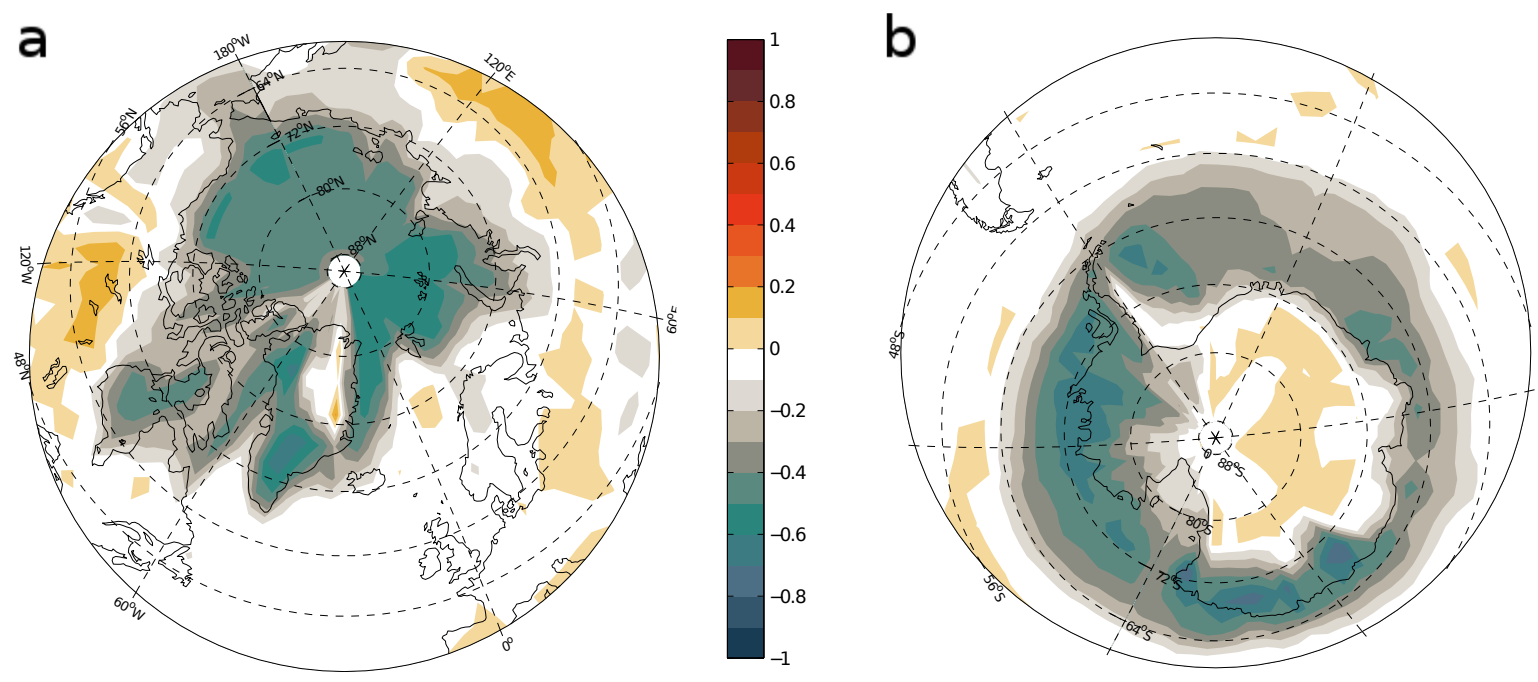

Fig. 7. Differences in albedo between mid-Pliocene and pre-industrial scenarios as calculated from upward and downward radiative fluxes for (a) northern, and (b) southern high latitudes.

Atlantic (2.5-4 $\mathrm{mm} \mathrm{d}^{-1}$, Fig. 9). Significant negative anomalies dominate low latitudes, in particular in the Atlantic, Indian Ocean and West Pacific. Boreal winter precipitation differences in the North Atlantic follow the pattern of positive SST anomalies (Fig. 5). Large positive and negative differences in the tropics and in low latitudes during boreal summers result from altered positions of the Intertropical Convergence Zone (ITCZ). As a result, drier-than-modern regions over the Atlantic, West Pacific, and Caribbean contrast with wetter-than-modern regions in the East Pacific and land areas in Africa, India and South East Asia, significantly affecting monsoonal behavior and magnitude.

\section{Discussion}

The modeled mid-Pliocene climate differs significantly from pre-industrial. Difference patterns correlate spatially with regions of altered boundary conditions. Polar amplification of warming is pronounced, forced mainly by prescribed Pliocene sea ice retreat, high-latitude SST warming, and reductions in Greenland and Antarctic ice sheet extents. Regional temperatures are impacted by prescribed changes in local topography, particularly in mountainous areas. Furthermore, we find that boundary conditions impact climate beyond local and regional scales, through their direct effects on the dynamics of the atmosphere. For instance, at mid and high latitudes, the North Atlantic/ Arctic Oscillation (NAO/AO) pattern is affected by a smaller Pliocene Greenland Ice Sheet and the combined feedbacks associated with SSTs and sea ice in the Arctic (not shown). At low latitudes, changes in SST patterns, such as the decrease in the Pacific zonal equatorial SST gradient in the Pliocene (not shown), noticeably affect atmospheric processes, with the potential of affecting the seasonality and magnitude of the El Niño/Southern Oscillation (ENSO) phenomenon and redefining the mean location of the ITCZ and hence the tropical precipitation patterns (monsoonal behavior). These climate drivers and their regional to global dynamics need further quantification through multi-model comparisons (PlioMIP intercomparison phase).

The spatial anomalies in temperature, surface energy balance and precipitation point to the importance of internal feedbacks in determining global climate. In particular, changes in vegetation distribution, sea ice extent and SSTs co-determine heat and moisture budgets and their transfer between the surface and atmosphere. The importance of vegetation feedback has been highlighted in studies of Quaternary glacial cycles (Claussen, 2009, and references therein) and recently for the Pliocene (Koenig et al., 2011). Given the magnitude of this feedback, further investigations using interactive climate-vegetation models could improve the understanding of climate-biosphere interactions in a warmer than modern world.

The PRISM3 multi-proxy reconstruction of mid-Pliocene SSTs is based on an extensive global network of available data (Dowsett et al., 2010). Nevertheless, sea-ice proxies are limited to particular regions, increasing the uncertainties in reconstructed mid-Pliocene sea ice extent and thickness. Given the importance of sea-ice feedbacks in the climate system, future investigations should target sea-ice reconstructions to improve model performance in simulating Pliocene high latitude climates.

The GENESIS GCM results for the Pliocene reveal a high degree of polar amplification (Figs. 6 and 8). The modeled Pliocene warming is significantly higher over regions 

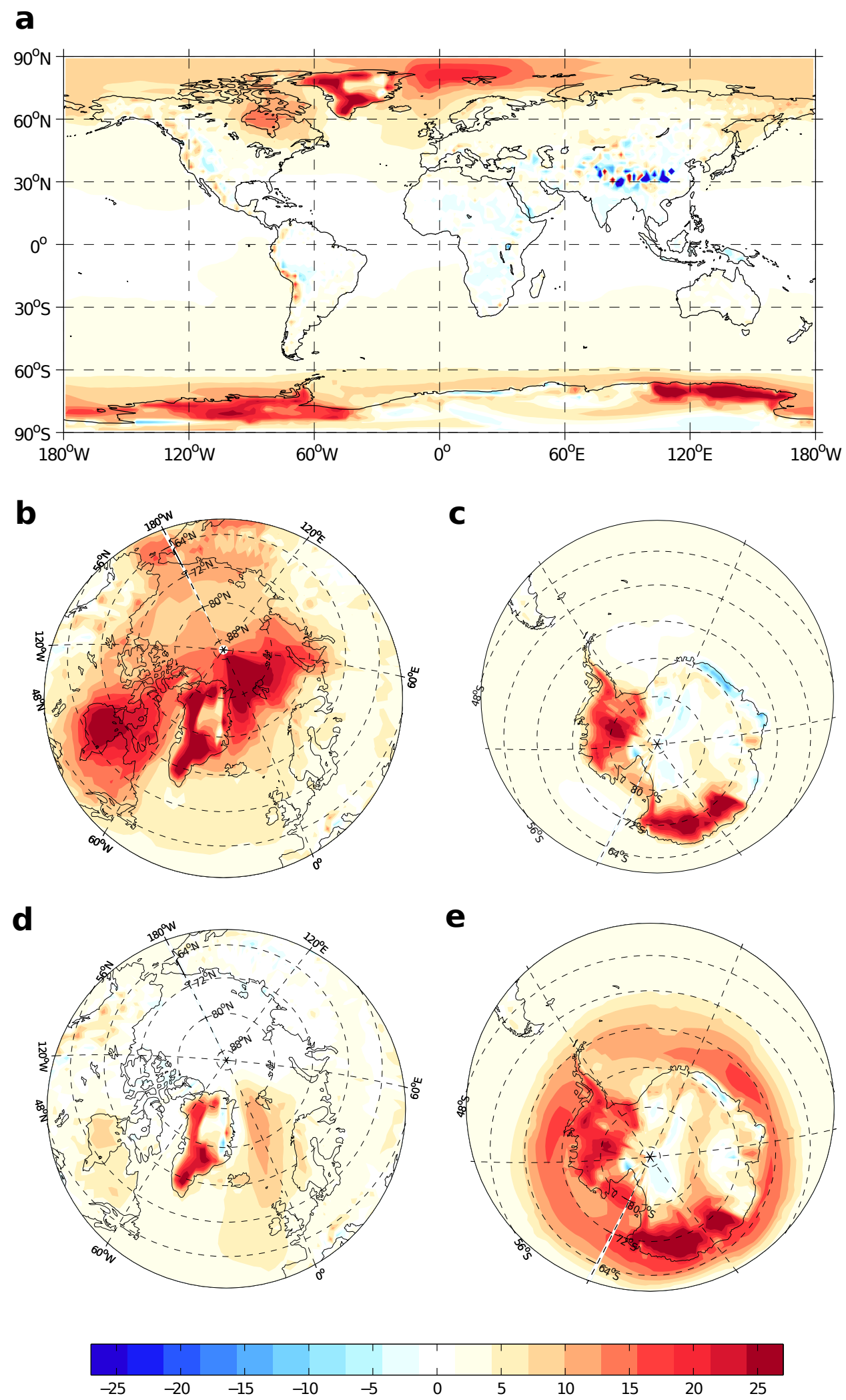

Fig. 8. Pliocene minus pre-industrial differences in model surface air temperatures $\left(2-\mathrm{m},{ }^{\circ} \mathrm{C}\right)$. (a) Annual, (b, c) December-January-February, (d, e) June-July-August. 


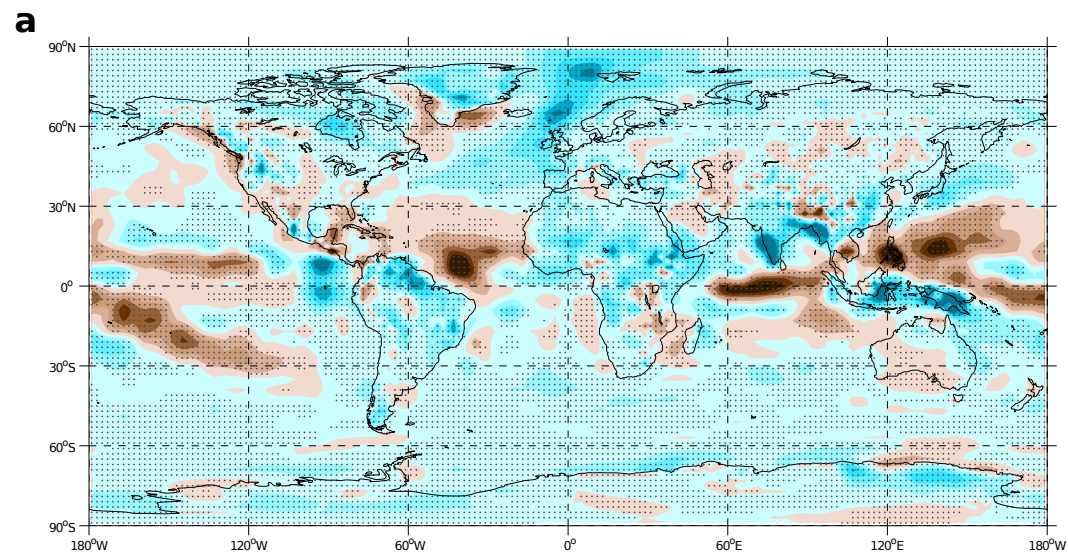

b
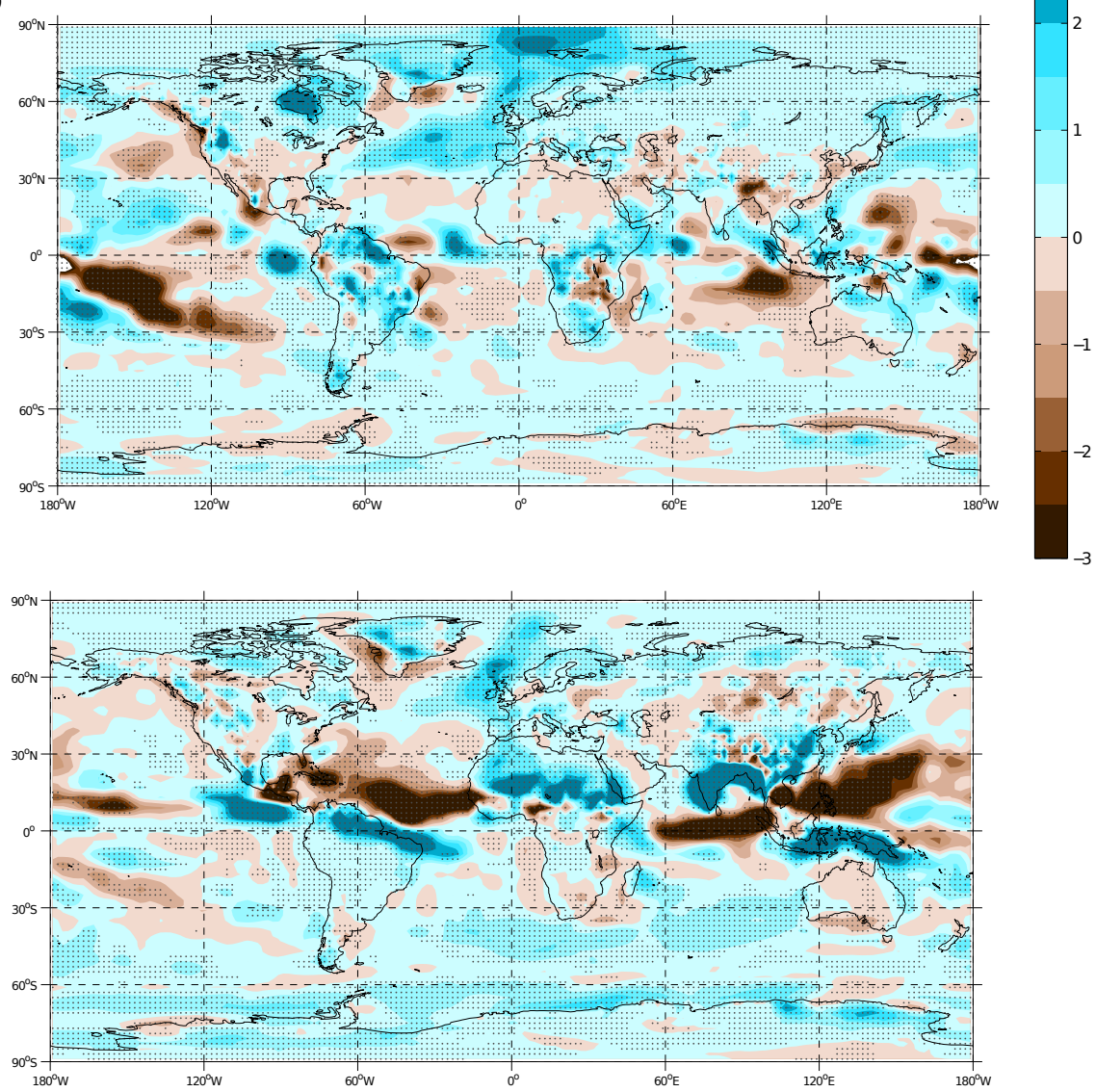

Fig. 9. Pliocene minus pre-industrial differences in model precipitation rates $\left(\mathrm{mm} \mathrm{d}^{-1}\right)$. (a) Annual, (b) December-January-February, (c) June-July-August. Significant differences (stippled) are inferred by a Student t-test.

of deglaciated Greenland and West and East Antarctica ice sheets. A few modeling studies have addressed Greenland and Antarctic ice sheet variability in both the midto late Pliocene, however the exact ice sheet extents and locations continue to be debated (Hill et al., 2007; Lunt et al., 2008; Pollard and DeConto, 2009; Dolan et al., 2011a; Koenig et al., 2011). To better constrain the response of the cryosphere to mid-Pliocene boundary conditions and forcings to reduce uncertainties associated with model dependencies and biases, a Pliocene ice-sheet model intercomparison project (PLISMIP) has been initiated and is currently underway (Dolan et al., 2011b). PLISMIP follows the PlioMIP framework, and deploys a hierarchy of standalone and coupled climate and ice sheet models and a set of Pliocene high-latitude boundary conditions to better constrain reconstructions of Pliocene ice sheets. 


\section{Conclusions}

In conclusion, PlioMIP provides a framework in which a data-driven model intercomparison can lead to a better understanding of climate dynamics in a warmer time, when ice sheets and sea ice cover were reduced, SSTs were warmer, and vegetation had adapted to the changed climate. Future modeling should attempt to disentangle forcing factors and quantify the contributions of internal feedbacks (Koenig et al., 2011). Along with proxy reconstructions, these activities will guide the analysis of specific regional aspects of mid-Pliocene warmth. As an initial step, this paper describes the implementation strategy of mid-Pliocene boundary conditions into the GENESIS GCM with relevance to ongoing data and modeling analyses within the PlioMIP framework and beyond.

Acknowledgements. This material is based on work supported by the US National Science Foundation under the award ATM0513402 .

Edited by: D. Lunt

\section{References}

Alder, J. R., Hostetler, S. W., Pollard, D., and Schmittner, A.: Evaluation of a present-day climate simulation with a new coupled atmosphere-ocean model GENMOM, Geosci. Model Dev., 4, 69-83, doi:10.5194/gmd-4-69-2011, 2011.

Bergengren, J. C., Thompson, S. L., Pollard, D., and DeConto, R. M.:Modeling global climate-vegetation interactions in a doubled $\mathrm{CO}_{2}$ world, Climatic Change, 50, 31-75, 2001.

Bigelow, N. H., Brubaker, L. B., Edwards, M. E., Harrison, S. P., Prentice, I. C., Anderson, P. M., Andreev, A. A., Bartlein, P. J., Christensen, T. R., Cramer, W., Kaplan, J. O., Lozhkin, A. V., Matveyeva, N. V., Murray, D. F., McGuire, A. D., Razzhivin, V. Y., Ritchie, J. C., Smith, B., Walker, D. A., Gajewski, K., Wolf, V., Holmqvist, B. H., Igarashi, Y., Kremenetskii, K., Paus, A., Pisaric, M. F. J., and Volkova, V. S.: Climate change and Arctic ecosystems: 1. Vegetation changes north of $55 \mathrm{~N}$ between the Last Glacial Maximum, mid-Holocene, and present, J. Geophys. Res., 108, D198170, doi:10.1029/2002JD002558, 2003.

Claussen, M.: Late Quaternary vegetation-climate feedbacks, Clim. Past, 5, 203-216, doi:10.5194/cp-5-203-2009, 2009.

Cogley, J. G.: GGHYDRO - Global hydrograhic Data Release 2.0, Department of Geography, Trent Univerisity, 1991.

DeConto, R. M., Pollard, D., and Harwood, D.: Sea ice feedback and Cenozoic evolution of Antarctic climate and ice sheets, Paleoceanography, 22, PA3214, doi:10.1029/2006PA001350, 2007.

Dolan, A. M., Haywood, A. M., Hill, D. J., Dowsett, H. J., Hunter, S. J., Lunt, D. J., and Pickering, S. J.: Sensitivity of Pliocene ice sheets to orbital forcing, Palaeogeogr. Palaeocl., 309, 98-110, doi:10.1016/j.palaeo.2011.03.030, 2011a.

Dolan, A. M., Koenig, S. J., Hill, D. J., Haywood, A. M., and DeConto, R. M.: Pliocene Ice Sheet Modelling Intercomparison Project (PLISMIP) - experimental design, Geosci. Model Dev. Discuss., 4, 2661-2686, doi:10.5194/gmdd-4-2661-2011, 2011.b.
Dorman, J. L. and Sellers, P. J.: A global climatology of albedo, roughness length and stomatal resistance for atmospheric general circulation models as represented by the Simple Biosphere Model, J. Appl. Meteorol., 28, 833-855, 1989.

Dowsett, H. J., Thompson, R., Barron, J., Cronin, T., Fleming, F., Ishman, S., Poore, R., Willard, D., and Holtz, T. R.: Joint investigations of the Middle Pliocene climate I: PRISM paleoenvironmental reconstructions, Glob. Planet. Change, 9, 169-195, 1994.

Dowsett, H., Robinson, M., Haywood, A., Salzmann, U., Hill, D., Sohl, L., Chandler, M., Williams, M., Foley, K., and Stoll, D.: The PRISM3D paleoenvironmental reconstruction, Stratigraphy, 7, 123-139, 2010.

Harrison, S. P. and Prentice, C. I.: Climate and $\mathrm{CO}_{2}$ controls on global vegetation distribution at the last glacial maximum: analysis based on palaeovegetation data, biome modelling and palaeoclimate simulations, Global Change Biol., 9, 983-1004, doi:10.1046/j.1365-2486.2003.00640.x, 2003.

Harrison, S. P., Yu, G., Takahara, H., and Prentice, I. C.: Palaeovegetation - Diversity of temperate plants in East Asia., Nature, 413, 129-130, 2001.

Haywood, A. M., Dowsett, H. J., Otto-Bliesner, B., Chandler, M. A., Dolan, A. M., Hill, D. J., Lunt, D. J., Robinson, M. M., Rosenbloom, N., Salzmann, U., and Sohl, L. E.: Pliocene Model Intercomparison Project (PlioMIP): experimental design and boundary conditions (Experiment 1), Geosci. Model Dev., 3, 227-242, doi:10.5194/gmd-3-227-2010, 2010.

Haywood, A. M., Dowsett, H. J., Robinson, M. M., Stoll, D. K., Dolan, A. M., Lunt, D. J., Otto-Bliesner, B., and Chandler, M. A.: Pliocene Model Intercomparison Project (PlioMIP): experimental design and boundary conditions (Experiment 2), Geosci. Model Dev., 4, 571-577, doi:10.5194/gmd-4-571-2011, 2011.

Hill, D. J., Haywood, A. M., Hindmarsh, R. C. A., and Valdes, P. J.: Characterizing ice sheets during the Pliocene: evidence from data and models, Deep-Time Perspectives on Climate Change: Marrying the Signal from Computer Models and Biological Proxies, 517-538, 2007.

Kaplan, J. O., Bigelow, N. H., Prentice, I. C., Harrison, S. P., Bartlein, P. J., Christensen, T. R., Cramer, W., Matveyeva, N. V., McGuire, A. D., Murray, D. F., Razzhivin, V. Y., Smith, B., Walker, D. A., Anderson, P. M., Andreev, A. A., Brubaker, L. B., Edwards, M. E., and Lozhkin, A. V.: Climate change and Arctic ecosystems: 2. Modeling, paleodata-model comparisons, and future projections, J. Geophys. Res., 108, 8171, doi:10.1029/2002JD002559, 2003.

Kiehl, J. T., Hack, J. J., Bonan, G. B., Boville, B. A., Williamson, D. L., and Rasch, P. J.: The National Center for Atmospheric Research Community Climate Model: CCM3*, J. Climate, 11, 1131-1149, 1998.

Kineman, J.: FNOC/NCAR global elevation, terrain, and surface characteristics, Digital Dataset, $28 \mathrm{MB}$, Boulder: NOAA National Geophysical Data Center, 1985.

Koenig, S. J., DeConto, R. M., and Pollard, D.: Late Pliocene to Pleistocene sensitivity of the Greenland Ice Sheet in response to external forcing and internal feedbacks, Clim. Dynam., 37, 1247-1268, doi:10.1007/s00382-011-1050-0, 2011.

Lapola, D. M., Oyama, M. D., Nobre, C. A., and Sampaio, G.: A new world natural vegetation map for global change studies, Anais da Academia Brasileira de Ciências, 80, 397-408, 2008. 
Lunt, D. J., Foster, G. L., Haywood, A. M., and Stone, E. J.: Late Pliocene Greenland glaciation controlled by a decline in atmospheric $\mathrm{CO}_{2}$ levels, Nature, 454, 1102-1105, 2008.

Mathieu, R., Pollard, D., Cole, J., and White, J.: Simulation of stable water isotope variations by the GENESIS GCM for modern conditions, J. Geophys. Res., 107, 1-18, 2002.

Pacanowski, R.: Documentation users guide and reference manual (MOM2, Version 2), Tech. rep., GFDL Ocean Tech. Rep. 3.2, Princeton, NJ, 1996.

Pagani, M., Liu, Z., LaRiviere, J., and Ravelo, A. C.: High Earth-system climate sensitivity determined from Pliocene carbon dioxide concentrations, Nat. Geosci., 3, 27-30, 2009.

Pollard, D. and DeConto, R. M.: Modelling West Antarctic ice sheet growth and collapse through the past five million years, Nature, 458, 329-332, 2009.

Pollard, D. and PMIP Groups: Comparisons of ice-sheet surface mass budgets from Paleoclimate Modeling Intercomparison Project (PMIP) simulations, Glob. Planet. Change, 24, 79-106, 2000.

Pollard, D. and Thompson, S. L.: Climate and ice-sheet mass balance at the last glacial maximum form the GENESIS VERSION 2 GLOBAL CLIMATE MODEL, Quat. Sci. Rev., 16, 841-863, 1997.

Prentice, I. C. and Jolly, D.: BIOME 6000 Participants MidHolocene and glacial-maximum vegetation geography of the northern continents and Africa, J. Biogeogr., 27, 507-519, 2000.
Ramankutty, N. and Foley, J. A.: Estimating historical changes in global land cover: Croplands from 1700 to 1992, Global Biogeochem. Cy., 13, 997-1027, 1999.

Shea, D. J., Trenberth, K. E., and Reynolds, R. W.: A global monthly sea surface temperature climatology, National Center for Atmospheric Research, 1991.

Thompson, S. L. and Pollard, D.: A global climate model (GENESIS) with a land-surface transfer scheme, Part II: $\mathrm{CO}_{2}$ Sensitivity, J. Climate, 8, 1104-1121, 1995.

Thompson, S. L. and Pollard, D.: Greenland and Antarctic mass balances for present and doubled atmospheric $\mathrm{CO}_{2}$ from the GENESIS version-2 global climate model, J. Climate, 10, 871900, 1997.

Webb, R. S., Rosenzweig, C. E., and Levine, E. R.: Specifying land surface characteristics in general circulation models: Soil profile data set and derived water-holding capacities, Global Biogeochem. Cy., 7, 97-108, 1993

Wohlfahrt, J., Harrison, S. P., and Braconnot, P.: Synergistic feedbacks between ocean and vegetation on mid-and high-latitude climates during the mid-Holocene, Climate Dynam., 22, 223238, 2004.

Zhou, J., Poulsen, C. J., Pollard, D., and White, T. S.: Simulation of modern and middle Cretaceous marine $\delta{ }^{18} \mathrm{O}$ with an oceanatmosphere general circulation model, Paleoceanography, 23, 111, doi:10.1029/2008PA001596, 2008. 